\title{
Impacts of Inundation on Bird Assemblages in Forests in and around a Hydrodam in Terengganu, Malaysia
}

(Kesan Banjir terhadap Himpunan Burung di Dalam Hutan dan Kawasan Sekitar Empangan Hidro di Terengganu, Malaysia)

\author{
FARAH SHAFAWATI MOHD-TAIB*, Siti NABILAH ISHAK, MOHAMMAD SAIFUl MANSOR \& SHUKOR MD-NOR
}

\begin{abstract}
Despite the increasing numbers of hydrodam worldwide, only a handful of studies evaluated their impacts on biodiversity. Compared to terrestrial animals, birds were thought to be less affected by inundation process, following impoundment. At the Hulu Terengganu Hydroelectric Dam in Peninsular Malaysia, our study compared species assemblages and diversity of birds within the dam area (i.e. the dam reservoir and catchment area) after recent logging and inundation in relation to a nearby forest logged 30 years ago. Using point count and mist-netting techniques, we recorded a total of 64 species (Shannon Index $\left.\left(H^{\prime}\right)=3.827\right)$ in the dam area and 91 species $\left(H^{\prime}=3.99\right)$ in historically-logged forests. Insectivore species richness was significantly higher in the historically-logged forests (Mann-Whitney: $Z=4.339, N=205, \mathrm{p}<0.005$ ). These results indicated that richness and diversity of bird species assemblages appear to decline following recent inundation phase. Nevertheless, the forests in the dam area still harbour charismatic species such as eagles (Family: Accipitridae) and hornbills (Family: Bucerotidae) which suggests that this habitat is relatively important for birds.
\end{abstract}

Keywords: Avian; hydroelectric dam; Kenyir; logging; Malaysia

\section{ABSTRAK}

Walaupun jumlah empangan hidro di seluruh dunia semakin meningkat, hanya segelintir kajian menilai kesannya terhadap kepelbagaian biologi. Berbanding dengan haiwan terestrial, burung dianggap kurang dipengaruhi oleh proses pembanjiran berikutan pengempangan. Di Empangan Hidroelektrik Hulu Terengganu di Semenanjung Malaysia, kami mengkaji dan membandingkan himpunan spesies dan kepelbagaian burung di dalam kawasan empangan (empangan dan kawasan tadahan) selepas pembalakan dan pembanjiran baru-baru ini berbanding dengan hutan berdekatan yang telah dibalak 30 tahun lalu. Dengan menggunakan teknik kiraan titik dan penjaringan, kami mencatatkan sejumlah 64 spesies (Indeks Shannon, $\left.H^{\prime}=3.827\right)$ di kawasan empangan dan 91 spesies $(H ’=3.99)$ di hutan yang telah lama dibalak. Kekayaan spesies burung insektivor jauh lebih tinggi di hutan yang telah lama dibalak (Mann-Whitney: $Z=$ 4.339, $N=205$, p <0.005). Keputusan ini menunjukkan bahawa kekayaan dan kepelbagaian spesies burung menurun selepas fasa pembanjiran. Walau bagaimanapun, hutan di kawasan empangan masih dapat dijumpai spesies karismatik seperti helang (Famili: Accipitridae) dan enggang (Famili: Bucerotidae) yang turut menunjukkan bahawa habitat ini adalah penting untuk burung secara relatif.

Kata kunci: Burung; empangan hidroelektrik; Kenyir; Malaysia; pembalakan

\section{INTRODUCTION}

More hydroelectric dams are being built to meet the energy demands of Malaysia's rapidly growing human population. Although they can also contribute to flood prevention (Luis et al. 2013), dams substantially alter the environment by reducing forest cover (Zhao et al. 2010). For example, the inundation phase then fragments once continuous forests to form land bridge islands (i.e. former hilltops). However, the impacts of the inundation following dam impoundment on biodiversity are not well-documented (Chikodzi et al. 2013; Winemiller 2016).

In tropical forest, the impacts of forest fragmentation have largely focused on taxa such as small mammals (Gibson et al. 2013) and birds (Watson et al. 2004). These studies generally highlighted the importance of larger forest fragments for the persistence of biodiversity, as smaller fragments potentially lose many of the resident species more rapidly. Native forest species were also found to be confined to larger patches compared to smaller patches (Mohd-Taib et al. 2016), as these species are particularly very sensitive to habitat disturbance and deforestation (Maas et al. 2009; Sodhi et al. 2005). Insectivorous birds, for example, are known to be most affected by habitat degradation, due to their specialized niches (Mansor \& Sah 2012a) and thus are most affected by resource depletion.

In Peninsular Malaysia, studies quantifying the impacts of dams have been mainly conducted in the state of Terengganu. For example, studies have investigated the impact of land-bridge islands on birds (Yong et al. 
2011), dung beetles (Qie et al. 2011) and butterflies (Yong et al. 2012). These studies mainly assessed species assemblages on the land-bridges islands after inundation phase. They found that larger islands had higher species richness than smaller islands, and the degree to which islands are isolated was also important. Smaller islands, nonetheless, harbored some species that were not present in the larger islands, suggesting the importance of small islands for bird species (Fischer \& Lindenmayer 2002). As birds are very sensitive to habitat disturbance (Peh et al. 2005; Yong 2009), the construction of dams and the resulting habitat loss may be detrimental to bird species assemblages. In fact, the occurrence of certain bird species can reflect the quality and the condition of an ecosystem (Leito \& Kuresoo 2004). Yong et al. (2011) demonstrated that insectivorous birds were highly affected by the area of land-bridge islands. To the best of our knowledge, however, no study has assessed the impact of the dam inundation phase on bird assemblages.

Here, we investigated the impacts of dam inundation on bird assemblages in the state of Terengganu, Peninsular Malaysia. We compared bird species richness and diversity in the dam (recently logged forests within the reservoirs and surrounding catchment) to that of a historicallylogged forest. Our findings will not only determine the feeding guild that is particularly vulnerable to inundation process, but also contribute towards the management of bird assemblages in the newly built hydrodam.

\section{MATERIALS AND METHODS}

\section{STUDY AREA}

We conducted our study in Puah Dam $\left(60 \mathrm{~km}^{2}\right)\left(\mathrm{N} 05^{\circ}\right.$ 09' 61 ", E $102^{\circ} 35^{\prime} 98^{\prime \prime}$ ), which is north of the existing Kenyir Dam in Hulu Terengganu District, Terengganu, Malaysia (Figure 1). It is around $50 \mathrm{~km}$ from the Bandar Gua Musang (T156) - Hulu Terengganu roadway and about $65 \mathrm{~km}$ west of Kuala Terengganu (Figure 1). The impounded river, Sungai Tembat is a tributary of the Sungai (River) Terengganu, where its tributaries rise in the mountainous interior of the State of Terengganu, where it borders with the States of Pahang and Kelantan. The lower few kilometres of each river above their confluence are inundated by the Kenyir reservoir.

Our study was conducted between August 2014 and January 2015 after inundation took place in October 2014. We divided the study area into two sites: the dam and the historically-logged forest, $\mathrm{Sg}$. Deka (N $05^{\circ} 01^{\prime} 81^{\prime}$, E $\left.102^{\circ} 53^{\prime} 40^{\prime \prime}\right)$. The dam consists of the reservoir and surrounding forest catchment, while the historically-logged forest (logged 30 years ago) is located $20 \mathrm{~km}$ away from the Puah reservoir.

\section{SAMPLING}

Two sampling methods were used in our study: Point count and mist netting. Point-counts were conducted in January
2015 within dam using a boat and in the historically-logged forest on foot, for one week each. The observations were carried out between 0700 and 1900 h every day. A total of 30 observation points were made at each site for duration of $10 \mathrm{~min}$ each. Two observers were involved in the bird count (FSMT and MSM). Species were identified with the aid of a pair of binocular $(10 \times 42)$ and the estimated number of individuals was recorded.

Mist netting was conducted in August 2014 and January 2015 for one week each, at the historicallylogged forests and dam site (after inundation took place), respectively. Two locations were selected for mist netting (site A and B). A total of 20 mist nets were deployed along an established trail with a distance approximately $50 \mathrm{~m}$ apart in the forest surrounding the dam and similarly in the historically-logged forest. Each mist net was $2.5 \times 9 \times 4$ $\mathrm{m}$ in dimension, with a $36 \mathrm{~mm}$ Diamond mesh size and a 3 -pouch construction. The nets were opened at $0700 \mathrm{~h}$ and closed at $1900 \mathrm{~h}$ and monitored every hour. The duration of mist netting at the same locations was regulated to prevent birds from becoming familiar with the mist nets (Robbins et al. 1992). The birds caught were measured and ringed before released. Bird identification was aided by Robson (2008), while feeding guild information was obtained from Mansor and Sah (2012b), Wells (1999, 2007), Wong (1986) and Yong et al. (2011).

\section{DATA ANALYSIS}

In order to characterize bird species distribution patterns at the two sites, we used non-parametric analysis, the Rank-abundance Curve (RAC) (Magurran 2004; Tokeshi 1993). Species were arranged in sequence from the most to the least abundant along the $x$-axis, while log abundance was plotted on the vertical or $y$-axis. Model verification will use PAST software version $2.17 \mathrm{c}$, which will give the Chi-square and p-value. Model with the lowest p-value will indicate the best model type. Using Ecosim software version 7.71, individual-based rarefaction curves (Gotelli \& Colwell 2001) were generated separately for each sampling technique (Magurran 2004). Several indices were calculated with PAST software. Shannon Index is a measure of diversity at a site and is influenced by the number of species present and species uniformity. Chao1 index gives an estimated species richness if sampling is prolonged. To compare species compositions between both sites, we use Jaccard Similarity Indexes (JSI) using MVSP (Multivariate Statistical Package) version 3.13b to determine the degree of similarity in species composition in both sites. Each species was assigned to specific feeding guild and significant differences between the group abundance for both sites were determined using the Mann-Whitney U test.

\section{RESULTS}

A total of 120 species from 37 families were recorded in both sites (Appendix A). The most dominant family 


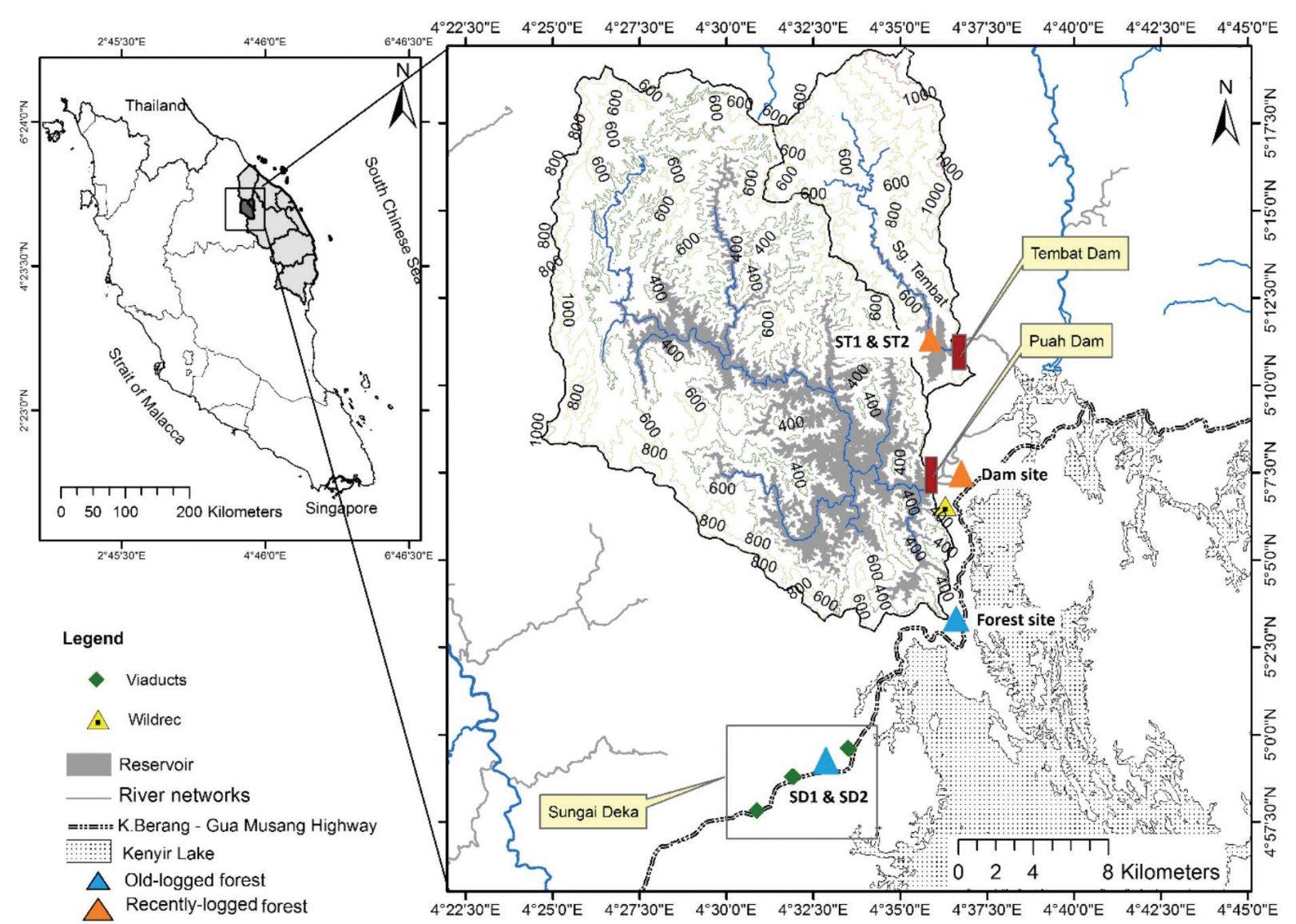

FIGURE 1. Location of our study in Hulu Terengganu district of the state of Terengganu, in Peninsular Malaysia

recorded at both sites was Timaliidae (16 species), followed by Pycnonotidae (14 species), Nectariniidae (10 species) and Muscicapidae (8 species). The Blackheaded Bulbul (Pycnonotus atriceps), Red-eye Bulbul (Pycnonotus brunneus) and Spectacled Bulbul (Pycnonotus erythrophthalmos) were relatively common in all study areas. The most abundant species recorded from mistnetting were the Little Spiderhunter (Arachnothera longirostra) ( $n=42,14.2 \%$ of total individuals recorded) and Grey-chested Spiderhunter (Arachnothera modesta) $(n=26,8.8 \%)$. Observation recorded Rhinocerous Hornbill (Buceros rhinoceros) $(n=15,10.3 \%)$ and Great Hornbill (Buceros bicornis) $(n=9,6.2 \%)$ in both areas. Species richness of birds was higher in the historically-logged forest (91 species) compared to the dam, which only recorded 63 species.

\section{SPECIES RICHNESS AND DIVERSITY PATTERN}

Rank abundance curves (RAC) for both mist netting and point counts (Figure 2(a) and 2(b)) shows two distinct relative abundance patterns at each sites. Based on mist netting, bird relative abundance at the two sites in the historically-logged forest exhibited a log-normal model, HLF_A $\left(\boldsymbol{\chi}^{2}=1.562, p=0.458\right)$ and HLF_B $\left(\boldsymbol{\chi}^{2}=2.905\right.$, $p=0.088)$, respectively. Bird relative abundance patterns at two locations in the dam, on the other hand, exhibited a log-series model, Dam_A $\left(\boldsymbol{\chi}^{2}=0.088, p=0.767\right)$ and Dam_B $\left(\boldsymbol{\chi}^{2}=0.169, p=0.6813\right)$, respectively. Based on point counts, a log-normal model was similarly observed for bird relative abundance patterns in the historicallylogged forest, $\left(\boldsymbol{\chi}^{2}=0.9338, p=0.3339\right)$, but a log-normal model $\left(\boldsymbol{\chi}^{2}=0.8456, p=0.358\right)$ was unexpectedly observed in the dam.

Individual rarefaction curves for both mist netting and point counts were shown in Figure 3(a) and 3(b). Species richness was higher in the historically-logged forest than in the dam (91 vs. 63 or 64 (Table 1), but there appeared to be no significant differences $(p>0.05)$. Based on mist netting data, the rarefaction curve of the historically-logged forest was reaching an asymptote, indicating high sampling efficiency compared to the dam. Interpolation point at 29th individual (which is the least number of individually captured in dam sites), showed a slightly higher average species in dam (21.02 \pm 2.98$)$, compared to the historically-logged forest $(18.51 \pm 4.49)$ species. Based on point count data, rarefaction curves show somewhat similar pattern in both sites. Once again, the historically-logged forest had higher species richness compared to the dam. Interpolation at $83 \mathrm{rd}$ individual showed a slightly higher average species richness at the historically-logged forest with $(38.29 \pm 2.71)$ compared to the dam $(33.85 \pm 2.15)$. 
(a)

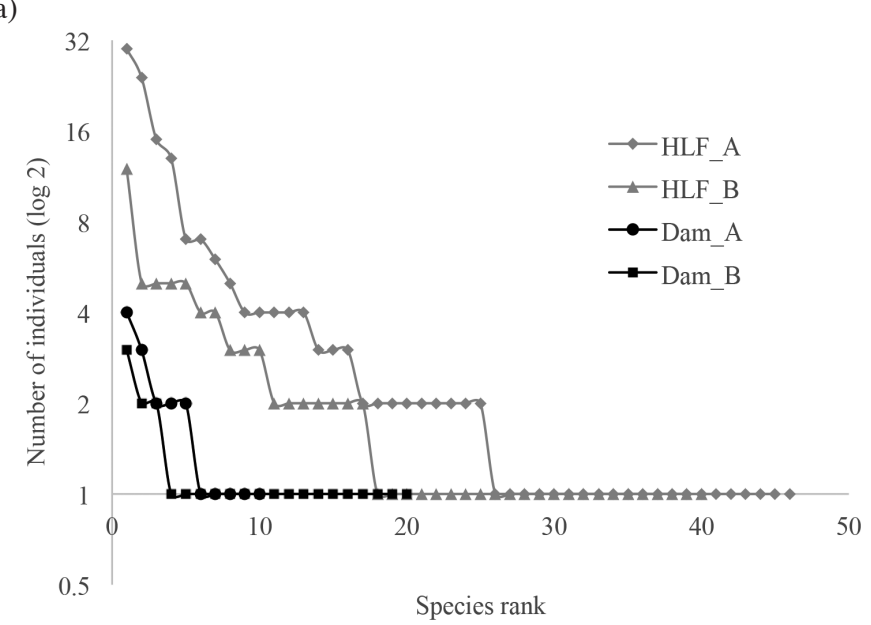

(b)

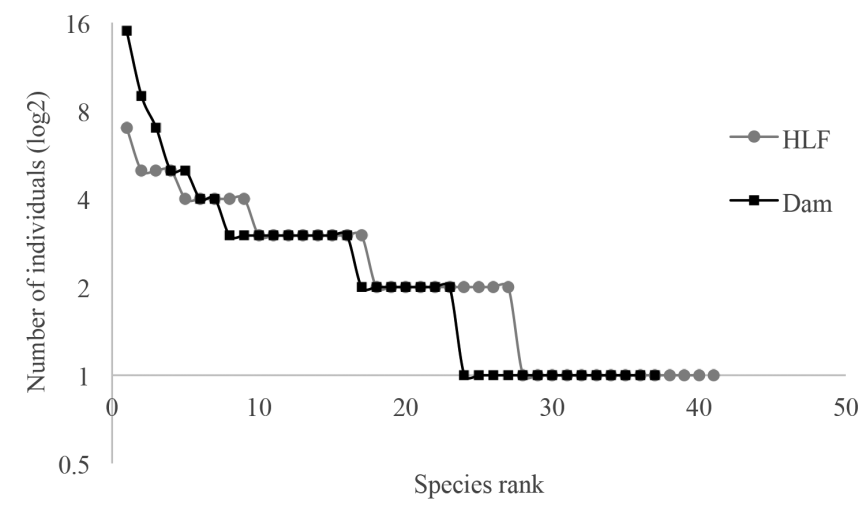

FIGURE 2. Rank abundance curve for (a) mist netting and (b) point count sampling in historically-logged forests (HLF) and the dam

Shannon diversity index was slightly higher in the historically-logged forest (3.99) compared to the dam (3.849), but the dominance index was similar in the historically-logged forest $(0.032)$ compared to dam area $(0.030)$. In contrast, the evenness index was lower $(0.5942)$ in the historically-logged forest than dam area (0.7335). Chao-1 index estimated that species richness in dam area could reach up to 105 (Table 1) and 109 species in the historically-logged forest.

\section{SPECIES COMPOSITION}

Of the total 120 species recorded in our study, 84 species are resident $(\mathrm{R})$ with five species having both resident and migrant status (R/M) and six migrant species (Appendix A). Species that have both resident and migrant status were the Asian Dollarbird (Eurystomus orientalis), Drongo cuckoo (Surniculus lugubris), Peregrine Falcon (Falco peregrinus), Asian Paradise Flycatcher (Terpsiphone paradise), Hill-blue Flycatcher (Cyornis banyumas) and Red-legged Crake (Rallina fasciata). Migrant species recorded were the Japanese Sparrowhawk (Accipiter gularis), Common kingfisher (Alcedo atthis), Oriental-dwarf Kingfisher (Ceyx erithacus), Asian
Brown Flycatcher (Muscicapa dauurica), Blue-throated Flycatcher (Cyornis rubeculoides) and Common Sandpiper (Actitis hypoleucos).

The Jaccard coeeficient showed a $28 \%$ similarity in species composition between the historically-logged forest and the dam. A total of 35 species were shared between these two areas such as Great Hornbill, Black-bellied Malkoha, Hill Myna and Large-billed Crow. Thirty species were exclusively recorded in the dam area, for instance, Grey-headed Canary-Flycatcher, Crested Goshawk and Japanese Sparrowhawk. In the historically-logged forest, 56 species were exclusively recorded.

Insectivorous birds were the most abundant feeding guild (53\%), followed by omnivores (25\%), carnivores (13\%), frugivores (6\%) and granivore (3\%). Insectivorous bird species were recorded more frequently in the historically-logged forest (49 species) than the dam area (28 species). Based on both sampling methods, insectivore species abundance was significantly higher in the historically-logged forest (Mann-Whitney: $\mathrm{Z}=4.339$, $n=205, p<0.005$ ), but no significant differences were found for other types of feeding guild. 
(a)

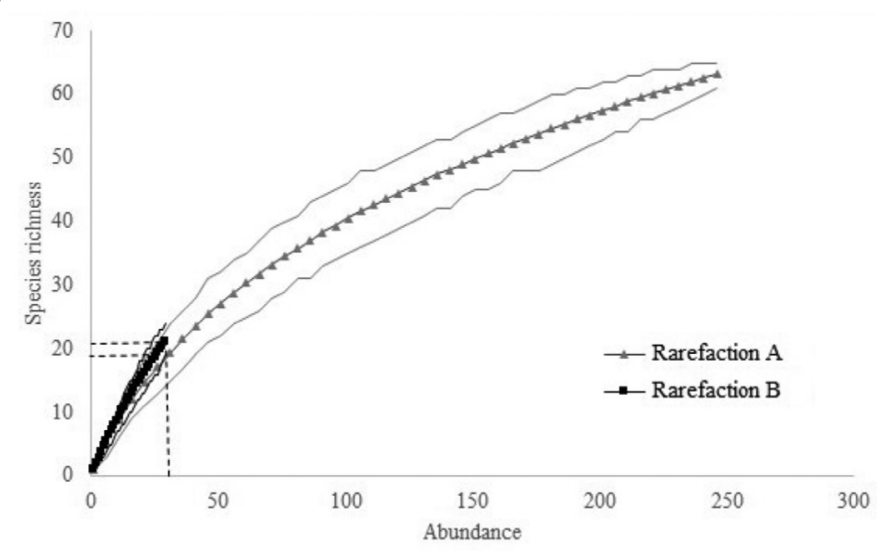

(b)

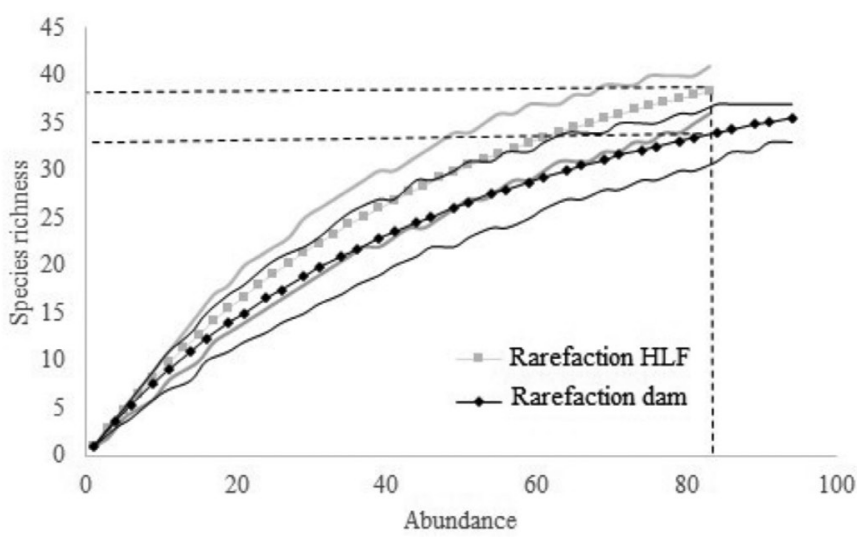

FIGURE 3. Rarefaction curves for a) mist netting and b) point count sampling in historically-logged forest (HLF) and the dam

\section{DISCUSSION}

To the best of our knowledge, our study is the first in Malaysia to quantify the richness and diversity of bird assemblages in forests around hydrodam just after its inundation phase. We found that bird species richness and diversity in the relatively more disturbed dam area was generally lower compared to a nearby historicallylogged forest area that has not been logged in 30 years. Based on our RAC analysis, the historically-logged forest fitted well with the log-normal model, indicated a mature community with an ideal species distribution model (Magurran 2004; Sugihara 1980). On the other hand, dam sites illustrated a log-series model which indicated an early stage of succession with high species dominance (Fisher et al. 1943; Motomura 1932). This finding is concordant with previous studies on avifaunal assemblages in forests of different degrees of disturbance (Hashim \& Ramli 2013; Johns 1989; Peh et al. 2005; Thiollay 1997). A high estimated species number at the dam area also suggests that ecological succession occurs following inundation.

This study also show that these sites harbour many highly protected species, for instance, the Blue-banded Kingfisher (Alcedo euryzona) is listed as critically endangered species according to the IUCN Red List of
Threatened Species (2017). Another 20 other species recorded from both site categories are listed as near threatened and the remaining species are listed as least concern (Appendix A).

Certain bird species are more easily detected in disturbed habitats, including recently logged forests (Woltmann 2003). Our study showed that the dam appears to harbour more species from Accipitridae and Bucerotidae families following the inundation phase, but less Passerines. Species from Accipitridae and Bucerotidae family were easily detected in the open environment of the dam. It is interesting to note the dominant of hornbills species through point count observation in the dam. This group of birds feed primarily on fruiting trees especially Ficus spp. (Wells 1999). The abundance of hornbills recorded during the inundation phase could be due to the fact that logging operations have avoided felling of fig trees, which are not highly valued in the timber industry due to their properties (Johns 1989). However, hornbill populations in the dam may decline over time because they can no longer find tall trees with cavities for nesting. Nevertheless, Ficus sp. in dam area appears to be attracting frugivorous species from the Family Pycnonotidae and sensitive species such as the Green Broadbill (Calyptomena viridis), which is a forest-specialist bird. 
TABLE 1. Bird diversity indices from our sampling in historically-logged forests and the dam in our study area

\begin{tabular}{lcc}
\hline & Historically-logged forest & Dam \\
\hline Taxa_S & 91 & 63 \\
Individuals & 361 & 149 \\
Dominance_D & 0.03225 & 0.03022 \\
Simpson_1-D & 0.9677 & 0.9698 \\
Shannon_H & 3.99 & 3.849 \\
Evenness_e^H/S & 0.5942 & 0.7335 \\
Fisher_alpha & 39.15 & 42.53 \\
Berger-Parker & 0.1163 & 0.1007 \\
Chao-1 & 109.5 & 105.3 \\
\hline
\end{tabular}

Several species from family Accipitridae were recorded perching and nesting at the tip of emergent trees now submerged by the dam, such the Crested Goshawk (Accipiter trivirgatus), Blyth's Hawk-eagle (Spizaetus alboniger) and Japanese Sparrowhawk (Accipiter gularis). Some of these species are montane forest inhabitants, but can now be found in hill-lowland forests. Our findings suggest that for now, certain species can still persist, but it remains to be seen whether the forests in the dam can support native forest species in the long run.

Bulbuls (Family: Pycnonotidae) made up the largest proportion of the total species captured in both areas and several species from this family is commonly found in the dam area. Most bulbul species are resilient to disturbance and are also considered as open country birds, which utilize open areas, such as parks, gardens and plantations. They are well-known as colonizing species and prefer to inhabit the logged forest. They are frugivores but also feed on insects, which has proven to be advantageous because they can tolerate seasonal variation in fruit abundance in logged forests (Wong 1986). The presence of fruit-eating birds may also speed up the recovery and successional process in regenerating forests through seed dispersal (Carlo \& Morales 2016).

Sensitive forest-dependent birds such as Timaliidae (Babblers) and Muscicapidae (Flycatchers) were poorly represented in the dam. Babbler species are forestdependent insectivores and have a low tolerance to habitat loss and degradation (Yong 2009). Flycatcher species such as Cyornis spp. are also more sensitive to disturbance than other genera (Lambert 1992). The presence of the Blue-throated Flycatcher (Cyornis rubeculoides) in the historically-logged forest albeit in low relative abundance, suggests that the forest is maturing and if left undisturbed could attract more forest-specialist species. The absence of such species in the dam reflects the loss of understorey vegetation and foraging substrata as well as associated preferred insect prey (Robinson 1969).

The after-effects of logging on birds have been documented in the literature. Johns (1989) stated that logging will have an impact on bird population for 12 years post-logging, particularly on native forest bird species. Species such as Rufous-winged Philentoma (Philentoma pyrhropterum), Asian Paradise Flycatcher (Terpsiphone paradise), Crested Jay (Platylophus galericulatus) and White-crowned Forktail (Enicurus leschenaultia) were only recorded in the historically-logged forests. In some areas, the bird assemblages in maturing-logged over forest may approach those of primary forests, even though it would be unlikely to reach the original species composition. Peh et al. (2005) reported that around 75\% of a bird species community was shared between logged and primary forest.

Edge-forest species such as Rufescent prinia (Prinia rufescens) and open country species such as munias were commonly recorded in the historically-logged forests. However, the Little Spiderhunter and Grey-breasted Spiderhunter were two most dominant species in this habitat. Spiderhunters feed on wild bananas (Musaceae), gingers (Zingiberaceae) and herbaceous plants that easily grow shortly after logging (Johns 1989). The absence of these species in the dam indicates that the forests are at a very early stage of regeneration.

\section{EFFECTS OF DAM INUNDATION OF DAM ON BIRD FEEDING GUILDS}

Secondary forests offer a wider variety of niches and higher levels of plant and insect diversity due to structurally complex habitat (Miller et al. 2004). The abundance of food resources (flowers, fruits, arthropods) most likely influence bird species richness and individual abundance in forests (Wong 1986). Our study demonstrated that insectivores were the more dominant feeding guild in the historically-logged forests compared to the dam. Zakaria et al. (2005) found that insectivorous bird species are usually adversely affected by logging activities and are therefore suitable indicators of forest health. The low detection rates of insectivorous birds in disturbed habitats were also reported by many studies (Bregman et al. 2014; Canaday 1997; Powell et al. 2015; Şekercioğlu et al. 2002; Sodhi et al. 2004). However, some bird guilds are more mobile and less susceptible to logging, as they might be using different patches of (logged) forests for different resource needs. Certain frugivores and nectarivores species, for example, may successfully forage in disturbed habitats at intermediate intensities, where food is more abundant, 
while still nesting in primary forests (van Heezik \& Seddon 2012). Thus, the abundance and richness of food resources, (e.g. fruits, seeds, insects and nectar) is a key in influencing the diversity and richness of bird guilds.

\section{CONCLUSION}

Due to our relatively small sample size (i.e. comparisons were made across two locations at most) and short sampling period (i.e. we only conducted two months of sampling), further research is needed to determine the extent to which bird assemblages are affected by postinundation phases of hydrodams over longer periods and larger spatial scales. It appears that insectivorous birds were the most vulnerable guild in our study site. Changes in species distribution in the dam areas, particularly at the newly formed islands are critical to determining the species turnover in the dam. Information regarding altitudinal ranges and other parameters of bird distributions are also required, such as habitat needs, foraging behaviour and habitat changes on ground-dwelling species, such as pheasants. Assessing the defining factors that govern the species composition and dynamics of tropical avifauna is certainly complex and difficult because detailed knowledge of ecology for bird species are often unavailable. When possible, future bird monitoring activities should take into account spatial and temporal distributions of populations, breeding activities, turnover rates and recruitment in the dam. Ultimately, we believe our findings can contribute to better management of bird and wildlife habitats in the hydrodam in our project site.

\section{ACKNOWLEDGEMENTS}

We thank Associate Professor Dr. Gopalasamy Reuben Clements for improving the manuscript. Sincere thank is also dedicated to all field assistants of Universiti Kebangsaan Malaysia and Wildlife Research Group UKM for providing assistance and accommodation during the field sampling. We would like to thank Tenaga Nasional Berhad (TNB) and Department of Wildlife and National Park of Malaysia (DWNP) for the opportunity to carry out this study. The project is funded by TNB (project code ST-2015-001).

\section{REFERENCES}

Bregman, T.P., Şekercioğlu, C.H. \& Tobias, J.A. 2014. Global patterns and predictors of bird species responses to forest fragmentation: Implications for ecosystem function and conservation. Biological Conservation 169: 372-383.

Canaday, C. 1997. Loss of insectivorous birds along a gradient of human impact in Amazonia. Biological Conservation 77: 63-77.

Carlo, T.M. \& Morales, J.M. 2016. Generalist birds promote tropical forest regeneration and increase plant diversity via rare-biased seed dispersal. Ecology 97(7): 1819-1831.

Chikodzi, D., Mutowo, G. \& Makaudze, B. 2013. Impacts of dam construction on tree species diversity in semi-arid regions:
The case of Ruti Dam in Zimbabwe. Greener Journal of Environmental Management and Public Safety 2(1): 16-21.

Fisher, R.A., Corbet, A.S. \& Williams, C.B. 1943. The relationship between the number of species and the number of individuals in a random sample of an animal population. Journal of Animal Ecology 12: 42-58.

Fischer, J. \& Lindenmayer, D.B. 2002. Small patches can be valuable for biodiversity conservation: Two case studies on birds in south-eastern Australia. Biological Conservation 106(1): 129-136.

Gibson, L., Lynam, A.J., Bradshaw, C.J.A., He, F., Bickford, D.P., Woodruff, D.S., Bumrungsri, S. \& Laurance, W.F. 2013. Near-complete extinction of native small mammal fauna 25 years after forest fragmentation. Science 341: 1508-1510.

Gotelli, N.J. \& Colwell, R.K. 2001. Quantifying biodiversity: Procedures and pitfalls in the measurement and comparison of species richness. Ecology Letters 4: 379-391.

Hashim, E. \& Ramli, R. 2013. Comparative study of understorey birds diversity inhabiting lowland rainforest virgin jungle reserve and regenerated forest. The Scientific World Journal 2013: $1-7$.

Johns, A.D. 1989. Recovery of a Peninsular Malaysian rainforest avifauna following selective timber logging: The first 12 years. Forktail 4: 89-105.

Lambert, F.R. 1992. The consequences of selective logging for Bornean lowland forest birds: Philosophical transactions. Biological Sciences 335(1275): 443-457.

Leito, A. \& Kuresoo, A. 2004. Preliminary results of a national bird monitoring programme in Estonia. In Proceedings of the International Conference: $13^{\text {th }}$ Meeting of the European Bird Cencus Council. Parnu, Estonia (2000). pp. 81-86.

Luis, J., Sidek, L.M., Desa, M.N.M. \& Julien, P.Y. 2013. Sustainability of hydropower as source of renewable and clean energy. IOP Conference Series: Earth and Environmental Science 16: 012050.

Maas, B., Putra, D.D., Waltert, M., Clough, Y., Tscharntke, T. \& Schulze, C.H. 2009. Six years of habitat modification in a tropical rainforest margin of Indonesia do not affect bird diversity but endemic forest species. Biological Conservation 142: 2665-2671.

Magurran, A.E. 2004. Measuring Biological Diversity. Oxford: Blackwell Science.

Mansor, M.S. \& Sah, S.A.M. 2012a. Foraging patterns reveal niche separation in tropical insectivorous birds. Acta Ornithologica 47(1): 27-36.

Mansor, M.S. \& Sah, S.A.M. 2012b. The influence of habitat structure on bird species composition in lowland Malaysian rain forests. Tropical Life Science Research 23(1): 1-14.

Miller, J.R., Dixon, M.D. \& Turner, M.G. 2004. Response of avian communities in large river flood plains to environmental variation at multiple scales. Ecological Applications 14(5): 1394-1410.

Mohd-Taib, F.S., Ramli, M., Ahmad, N. \& Md-Nor, S. 2016. Species richness and turnover of birds in thirty years in the fragmented Bangi Forest Reserve, Selangor, Malaysia. Malaysian Nature Journal 68(1\&2): 229-239.

Motomura, I. 1932. On the statistical treatment of communities. Zoological Magazine 44: 379-383.

Peh, K.S.H., Jong, J.J., Sodhi, N.S., Lim, S.L.H. \& Yap, C.A.M. 2005. Lowland rainforest avifauna and human disturbance: Persistence of primary forest birds in selectively logged forests and mixed-rural habitats of southern Peninsular Malaysia. Biological Conservation 123: 489-505. 
Powell, L.L., Cordeiro, N.J . \& Stratford, J.A. 2015. Ecology and conservation of avian insectivores of the rainforest understory: A pantropical perspective. Biological Conservation 188: 1-10.

Qie, L., Lee, T.M., Sodhi, N.S. \& Lim, S.L.H. 2011. Dung beetle assemblages on tropical land-bridge islands: Small island effect and vulnerable species. Journal of Biogeography 38(4): 792-804.

Robbins, C.S., Dowell, B.A., Dawson, D.K., ColoÂn, J.A., Estrada, R., Sutton, A., Sutton, R. \& Weyer, D. 1992. Comparison of Neotropical migrant landbird populations wintering in tropical forest, isolated forest fragments, and agricultural habitats. In Ecology and Conservation of Neotropical Migrant Landbirds, edited by Hagan, J.M., Johnston, D.W. \& Manomet Bird Observatory (Mass.). Washington: Smithsonian Institution. pp. 207-220.

Robinson, M.H. 1969. The defensive behavior of some orthopteroid insects from Panama.Transactions of the Royal Entomological Society of London 121: 281-303.

Robson, C. 2008. A Field Guide to the Birds of South-East Asia. London: New Holland Publishers.

Saunders, D.A., Hobbs, R.J. \& Margules, C.R. 1991. Biological consequences of ecosystem: A review fragmentation. Conservation Biology 5: 18-32.

Şekercioğlu, Ç.H., Ehrlich, P.R., Daily, G.C., Aygen, D., Goehring, D. \& Sandí, R.F. 2002. Disappearance of insectivorous birds from tropical forest fragments. Proceedings of the National Academy of Sciences USA 99(1): 263-267.

Sodhi, N.S., Koh, L.P., Prawiradilaga, D.M., Darjono, Tinulele, I. Putra, D.D. \& Tan, T.H.T. 2005. Land use and conservation value for forest birds in Central Sulawesi, Indonesia. Biological Conservation 122: 547-558.

Sodhi, N.S., Liow, L.H. \& Bazzaz, F.A. 2004. Avian extinctions from tropical and subtropical forests. Annual Review of Ecology, Evolution and Systematics 35: 323-345.

Sugihara, G. 1980. Minimal community structure: An explanation of species abundance patterns. American Naturalist 116: 770-787.

Thiollay, J.M. 1997. Disturbance, selective logging and bird diversity: A neotropical forest study. Biodiversity and Conservation 6(8): 1155-1173.

Tokeshi, M. 1993. Species abundance patterns and community structure. Advances in Ecological Research 24: 112-186.

van Heezik, Y. \& Seddon, P.J. 2012. Accounting for delectability when estimating avian abundance in an urban area. New Zealand Journal of Ecology 36(3): 1-7.

Watson, J.E.M., Whittaker, R.J. \& Dawson, T.P. 2004. Avifaunal responses to habitat fragmentation in the threatened littoral forests of south-eastern Madagascar. Journal of Biogeography 31(11): 1791-1807.
Wells, D.R. 2007. The Birds of the Thai-Malay Peninsula. Vol. 2. The Passerine. London: Christopher Helm.

Wells, D.R. 1999. The Birds of the Thai-Malay Peninsula. Vol 1. Non-passerines. London: Academic Press.

Winemiller, K.O. 2016. Balancing hydropower and biodiversity in the Amazon, Congo, and Mekong. Development and Environment Science 351(6269): 128-129.

Woltmann, S. 2003. Bird community responses to disturbance in a forestry concession in lowland Bolivia. Biodiversity Conservation 12: 1921-1936.

Wong, M. 1986. Trophic organization of understorey birds in a Malaysian Dipterocarp forest. The Auk 103: 100-116.

Yong, D.L. 2009. Persistence of babblers (Timaliidae) communities in Singapore forests. Nature in Singapore 2: 365-371.

Yong, D.L., Lohman, D.J., Weei Gan, C., Qie, L. \& Lim, S.L.H. 2012. Tropical butterfly communities on land-bridge islands in peninsular Malaysia. Raffles Bulletin of Zoology 25: 161172.

Yong, D.L., Qie, L., Sodhi, N.S., Koh, L.P., Peh, K.S., Lee, T.M., Lim, H.C. \& Lim, S.L.H. 2011. Do insectivorous bird communities decline on land-bridge forest islands in Peninsular Malaysia. Journal of Tropical Ecology 27(1): 1-4.

Zakaria, M., Leong, P.C. \& Yusuf, M.E. 2005. Comparison of species composition in three forest types: Towards using bird as indicator of forest ecosystem health. Journal of Biological Sciences 5(6): 734-737.

Zhao, Q., Liu, S.\& Dong, S. 2010. Effect of dam construction on spatial-temporal change of land use: A case study of Manwan, Lancang River, Yunnan, China. Procedia Environmental Sciences 2: 852-858.

School of Environmental Science \& Natural Resources Faculty of Science and Technology

Universiti Kebangsaan Malaysia 43600 UKM Bangi, Selangor Darul Ehsan Malaysia

*Corresponding author; email: farah_sh@ukm.edu.my

Received: 15 February 2017

Accepted: 27 April 2018 


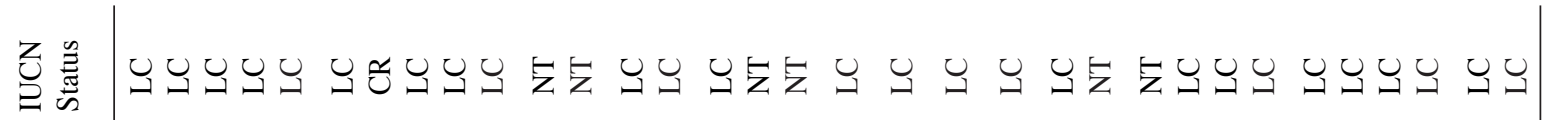

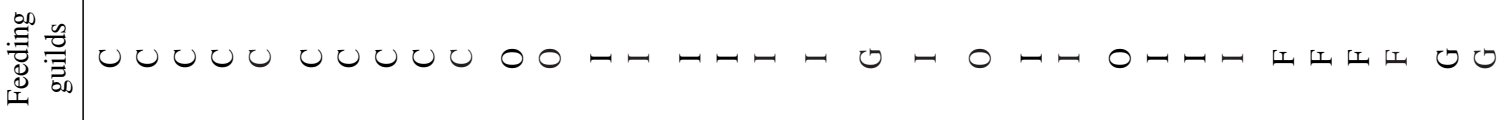

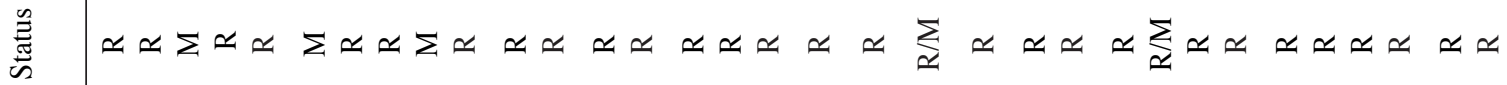

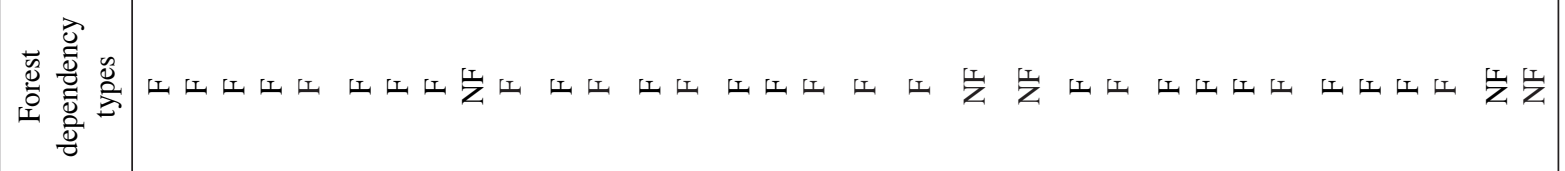

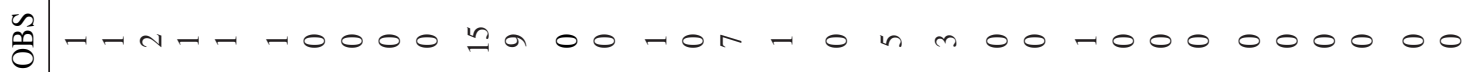
菊 $\sum_{\Sigma}^{T} 0000-0000-00-1-1000000000-0-000000$ $\bar{z} 1000000000000000000000000000000000$

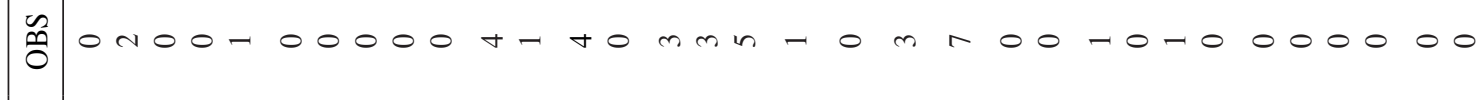

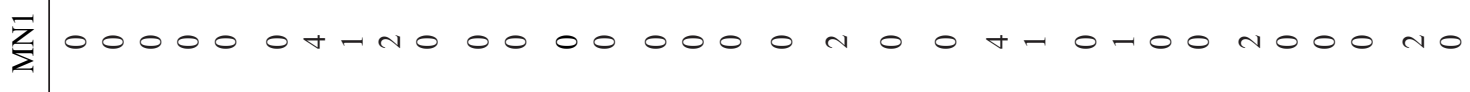

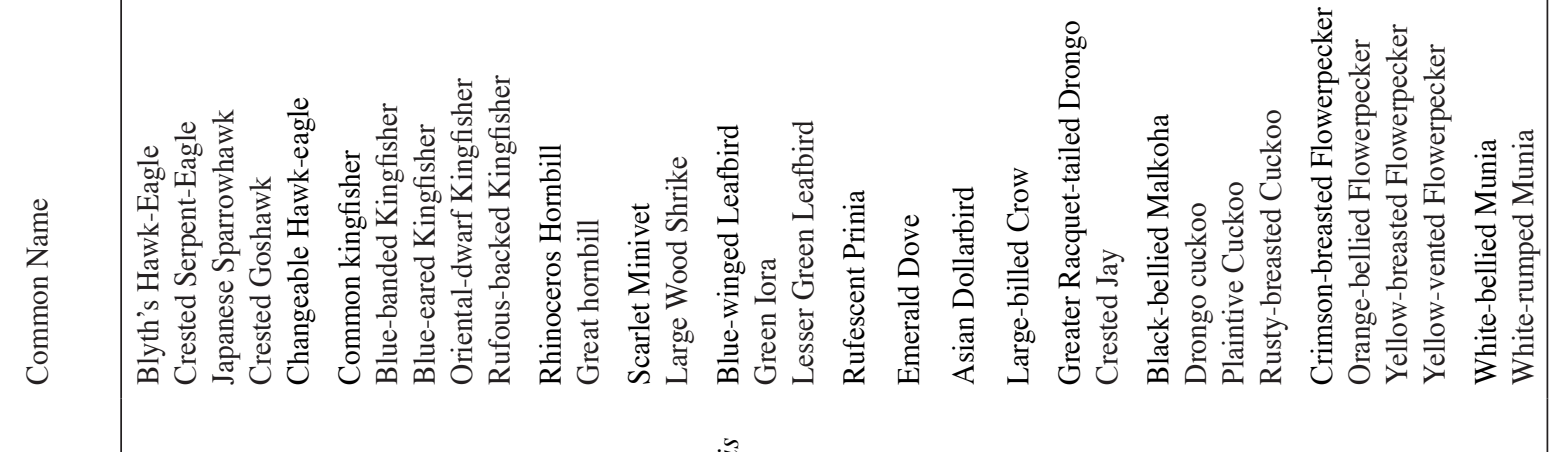

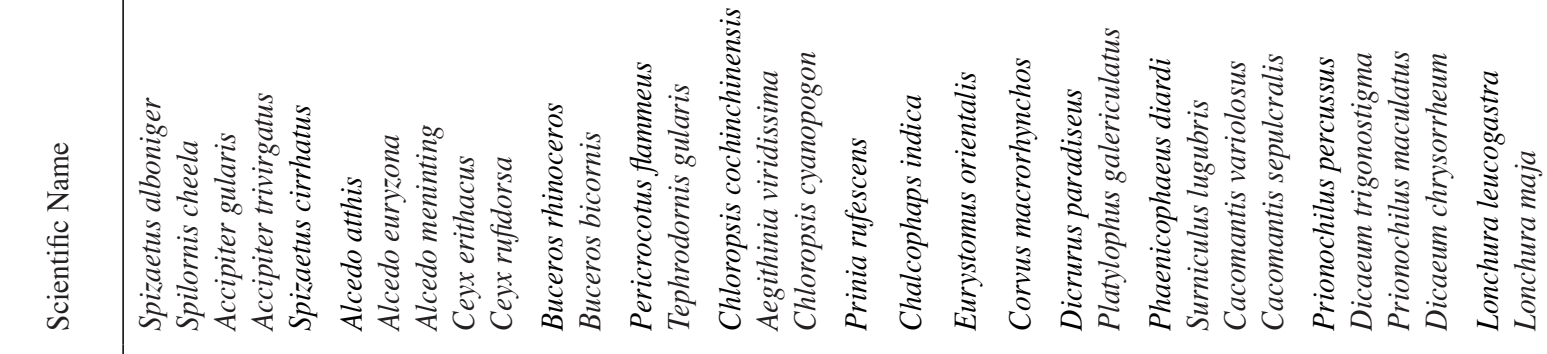

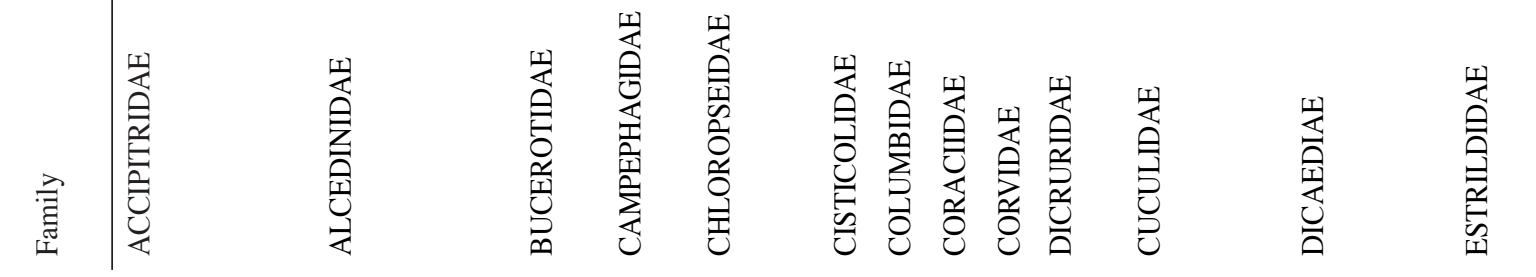




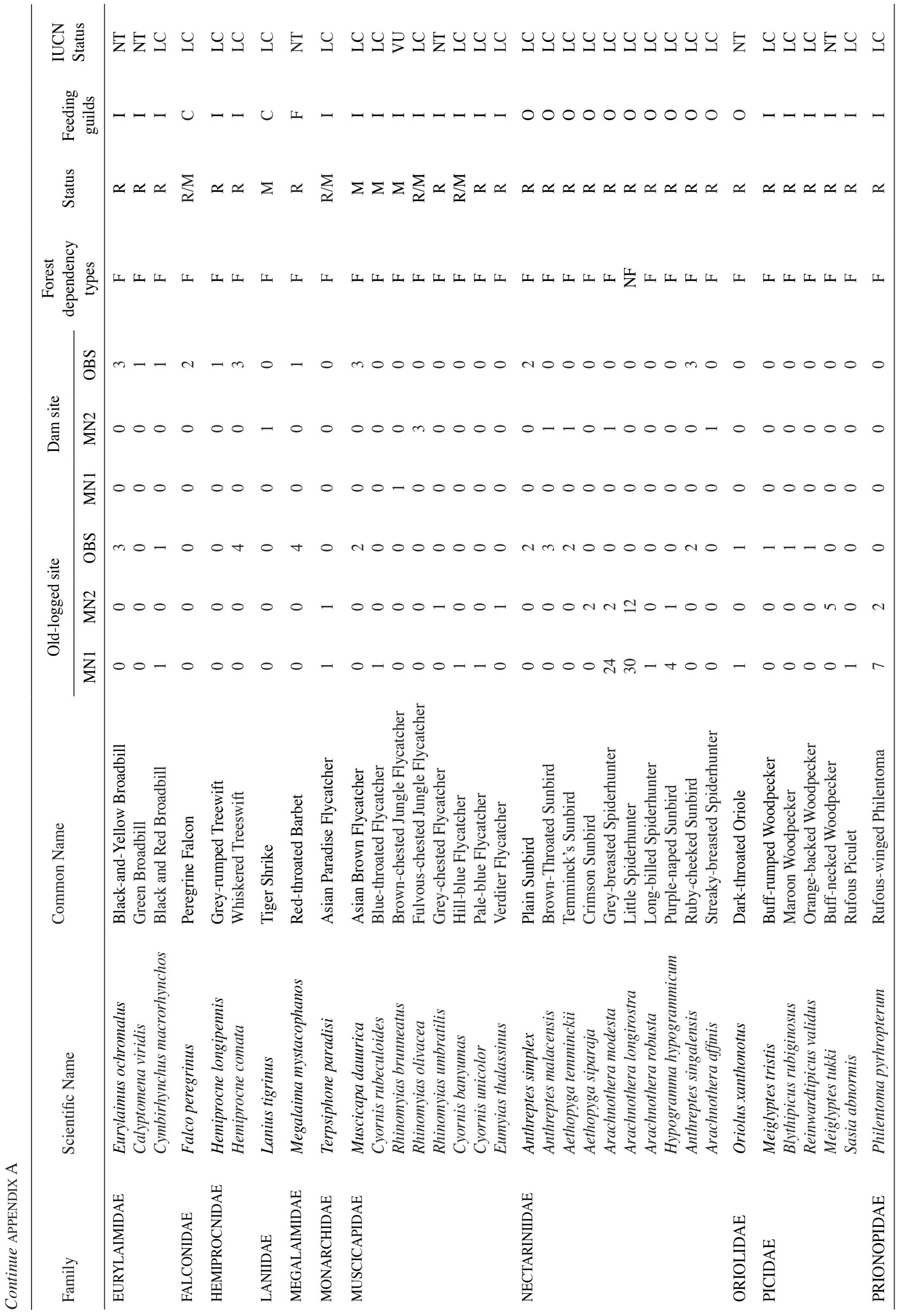




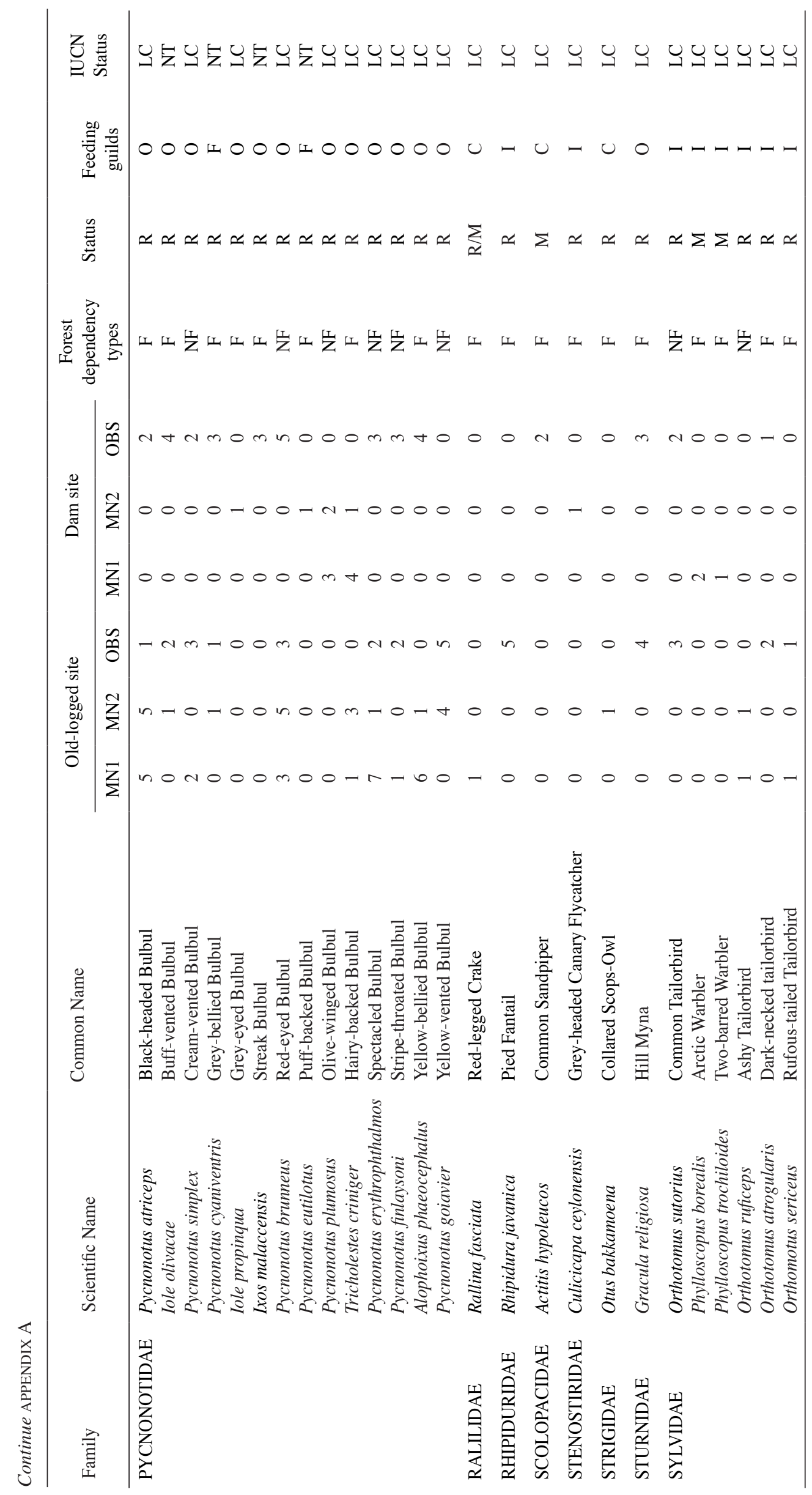




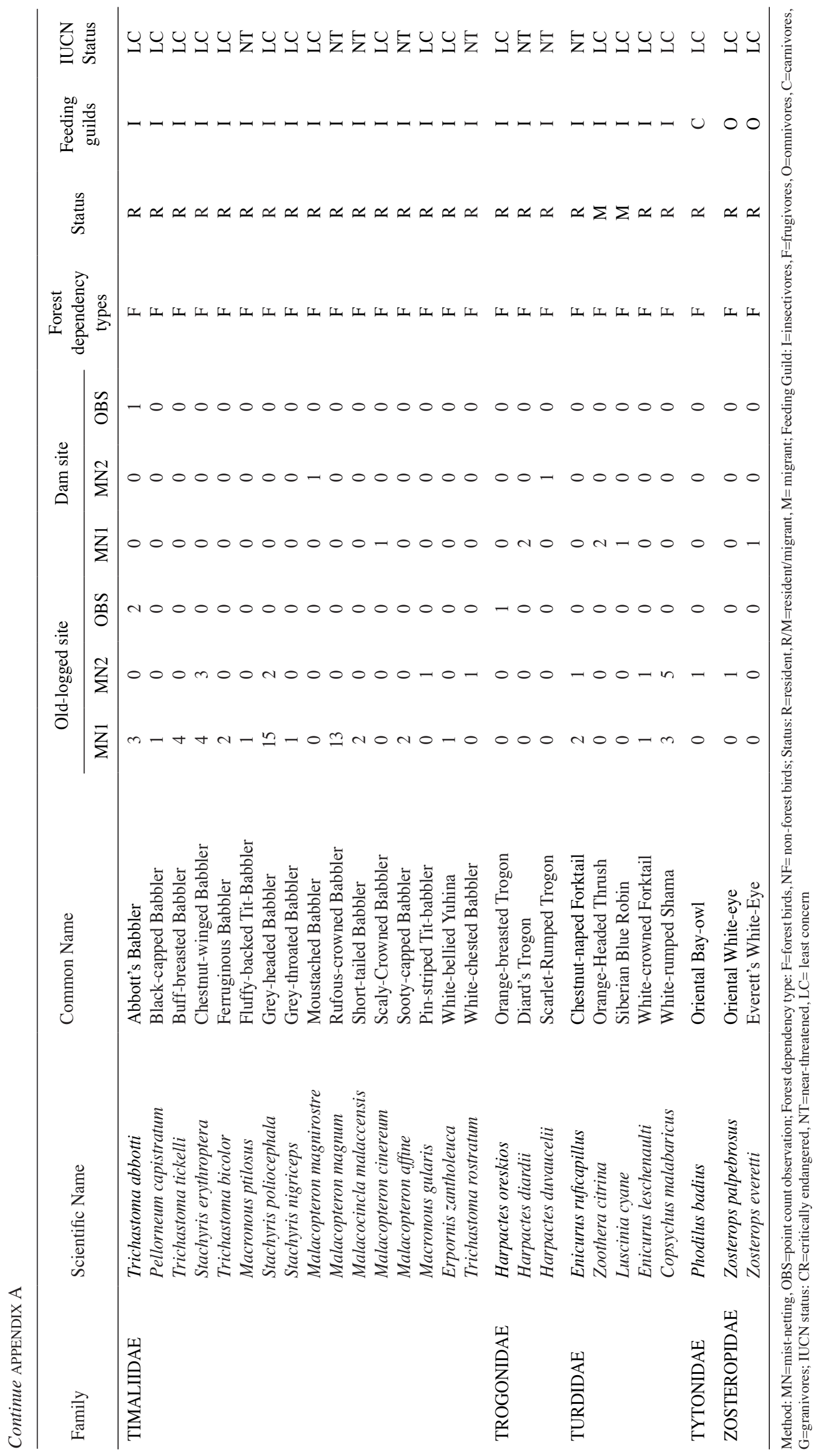

